\title{
AKOMODASI KOMUNIKASI ETNIS TIONGHOA DAN SUNDA DI SURYA KENCANA BOGOR
}

\author{
Aprilyanti Pratiwi ${ }^{1}$, Regiant Fachturahman Nurlatif ${ }^{2}$ dan M. Girindra Madanacaragni ${ }^{3}$ \\ 1, 2,3Universitas Pancasila, Jakarta - Indonesia \\ aprilyantipratiwi@univpancasila.ac.id
}

\begin{abstract}
The purpose of this study was to identify the communication accommodation process carried out by ethnic Chinese and Sundanese in Surya Kencana, Bogor. The theory used in this study is Howard Giles' Accommodation Communication Theory (CAT). The results showed that the Chinese ethnic Surya Kencana initially made communication accommodations due to compulsion. However, over time and the positive feedback given by the Sundanese Surya Kencana, the Chinese finally made communication accommodations naturally. In the process of communication accommodation, the two ethnics converged, diverged and overaccomodated. The convergence carried out by Chinese is to use Indonesian mixed with Sundanese when communicating with Sundanese. The convergence carried out by the Sundanese is addressing the Chinese with ethnic greetings, (ko ko and ci ci). The divergence made by the Chinese is to be proud if they are called according to their ethnic origin. Meanwhile, the divergence made by Sundanese is to use Sundanese in a larger portion when interacting with ethnic Chinese. The over-accommodation made by the Chinese ethnic group is saying the word Alhamdulillah when interacting with the Sundanese group so that it seems forced. The over-accommodation made by the Sundanese is to greet the Chinese with a greeting according to their ethnicity but not according to the age context, so it seems impolite.
\end{abstract}

Keywords: Accommodation Communication Theory; Chineese; Sundanese; Surya Kencana Bogor

\begin{abstract}
Abstrak
Tujuan penelitian ini adalah mengidentifikasi proses akomodasi komunikasi yang dilakukan oleh etnis Tionghoa dan Sunda di Surya Kencana, Bogor. Teori yang digunakan pada penelitian ini adalah Accommodation Communication Theory (CAT) milik Howard Giles. Hasil penelitian menunjukkan bahwa etnis Tionghoa Surya Kencana awalnya melakukan akomodasi komunikasi dikarenakan keterpaksaan. Namun seiring waktu dan adanya umpan balik positif yang diberikan etnis Sunda Surya Kencana, akhirnya etnis Tionghoa pun melakukan akomodasi komunikasi dengan alamiah. Pada proses akomodasi komunikasi, kedua etnis melakukan konvergensi, divergensi dan akomodasi berlebihan. Konvergensi yang dilakukan oleh etnis Tionghoa adalah menggunakan Bahasa Indonesia yang dicampur bahasa Sunda saat berkomunikasi dengan etnis Sunda. Konvergensi yang dilakukan oleh etnis Sunda adalah menyapa etnis Tionghoa dengan sapaan sesuai etnisnya, misalnya ko ko dan $c i$ ci. Divergensi yang dilakukan etnis Tionghoa adalah bangga jika dipanggil sesuai panggilan asal etnisnya. Sedangkan divergensi yang dilakukan etnis Sunda adalah menggunakan bahasa Sunda dengan porsi yang lebih banyak ketika berinteraksi dengan etnis Tionghoa. Akomodasi berlebihan yang dilakukan oleh etnis Tionghoa adalah mengucapkan kata Alhamdulillah saat berinteraksi dengan etnis Sunda sehingga terkesan dipaksakan. Sedangkan akomodasi berlebihan yang dilakukan oleh etnis Sunda adalah menyapa etnis Tionghoa dengan sapaan sesuai etnisnya tetapi tidak sesuai konteks usia, padahal tindakan tersebut terkesan tidak sopan.
\end{abstract}

Kata Kunci: Etnis Sunda; Etnis Tionghoa; Surya Kencana Bogor; Teori Akomodasi Komunikasi

\section{PENDAHULUAN}

Sejarah mencatat bahwa etnis Tionghoa di Indonesia mengalami kisah yang kelam. Padahal waktu awal kedatangannya ke
Nusantara, etnis Tionghoa dan masyarakat lainnya hidup rukun dan harmonis. Kala itu sebagai pendatang, masyarakat etnis Tionghoa hidup membaur dengan masyarakat sekitar 
(Carey, 2015). Kelamnya sejarah etnis Tionghoa di Indonesia diawali pada peristiwa pembantaian etnis Tionghoa oleh VOC pada tahun 1740 di Batavia dan sekitarnya. Penyebab pembantaian diakibatkan oleh kekhawatiran VOC terhadap harmonisnya hubungan antara etnis Tionghoa dan masyarakat sekitar (Vermeulen, 2010).

Kisah kelam pun berlanjut ketika etnis Tionghoa menjadi sasaran dan dibantai saat Perang Jawa pada tahun 1825. Tua, muda, anakanak, laki-laki dan perempuan menjadi korban pembantaian. Pembantaian yang terjadi merupakan imbas dari adanya rasa benci masyarakat Jawa terhadap etnis Tionghoa. Mereka yang awalnya hidup rukun dan damai kemudian mengalami konflik (Carey, 2015).

Hubungan Tionghoa-non Tionghoa kembali memanas akibat peristiwa rasial yang terjadi di Surakarta. Etnis Tionghoa mendapat stigma dan citra yang negatif oleh masyarakat Surakarta. Hal ini sangat bertolak belakang dengan peran etnis Tionghoa yang ikut membentuk dan mengembangkan kebudayaan Jawa (Rustopo, 2007). Pada era Orde Baru, stigma yang muncul dalam masyarakat non Tionghoa untuk masyarakat Tionghoa adalah adanya kecemburuan ekonomi. Surakarta didominasi oleh pengusaha-pengusaha Tionghoa. Jarak yang terbentang pun semakin jauh, kaum kaya didominasi oleh etnis Tionghoa, sedangkan etnis non Tionghoa hanya sebagai pekerja dan buruh yang menerima upah rendah (Onghokman, 2008). Ketegangan kecil ini pun berubah menjadi besar hingga terjadilah tragedi rasial di Surakarta pada 1972 dan 1998. Korban jiwa berjatuhan. Pertokoan, perkantoran dan rumah-rumah dibakar (Putro et.al, 2017).

Etnis Tionghoa mengalami tekanan terus-menerus di rezim Orde Baru. Mereka 'dipaksa' untuk berasimilasi dengan kebudayaan Indonesia, salah satunya dalam aspek nama (Suryadinata, 2010). Kekhawatiran terhadap adanya isu SARA yang sering kali muncul pada rezim Orde Baru menyebabkan etnis Tionghoa Indonesia harus mengganti nama mereka dengan nama Indonesia (Suharyo, 2013).
Berdasarkan kisah-kisah pembantaian serta diskriminasi terhadap etnis Tionghoa tersebut dapat disimpulkan bahwa, etnis Tionghoa selalu dijadikan kambing hitam dalam kehidupan bermasyarakat di Indonesia. Terlebih Suhandinata (2018) menemukan bahwa etnis Tionghoa menerima berbagai tuduhan negatif dari etnis non Tionghoa, diantaranya tidak memiliki rasa kebangsaan, selalu memikirkan keuntungan, dan tidak memiliki rasa empati terhadap orang-orang dari etnis lain. Etnis Tionghoa juga terkesan eksklusif karena hanya tinggal berdekatan dengan sesama mereka dan memiliki sifat angkuh.

Kisah yang berbeda dari kisah kelam etnis Tionghoa di atas justru kita temui pada beberapa daerah di Indonesia yang menggambarkan keharmonisan hubungan Tionghoa-non Tionghoa. Seperti yang terjadi di Kecamatan Lasem, Kabupaten Rembang, Jawa Tengah. Sejarah toletansi dan harmonisasi antara Tionghoa-Jawa di Lasem tertoreh nyata. Kedua etnis ini hidup rukun dan damai dalam segala aspek kehidupan, diantaranya dalam aspek ekonomi dan sosial. Ketika Indonesia dijajah Belanda pun, etnis Tionghoa dan Jawa bergandengan tangan melawan penjajah (Atabik, 2016).

Kehidupan masyarakat etnis Tionghoa dan Bali di desa Pupuan, Tabanan, Bali pun sangat harmonis. Walaupun etnis Tionghoa di desa Pupuan merupakan etnis minoritas, akan tetapi hubungan yang terjalin selaras dan koheren. Harmonisnya kehidupan kedua etnis ini di sana dapat dilihat dari perkawinan yang dilakukan oleh kedua etnis dan ritual yang dilakukan oleh etnis Tionghoa yang serupa dengan agama Hindu (Aryana, 2017).

Gambaran yang kurang lebih sama juga dapat kita lihat pada masyarakat TionghoaSunda di Bogor. Jalan Surya Kencana, sebagai salah satu kawasan pecinan di Kota Bogor, menjadi saksi betapa harmonisnya kedua enis tersebut. Kedua etnis ini hidup berdampingan bersama selama ratusan tahun tanpa adanya konflik. Hubungan kedua etnis tersebut di Jalan Surya Kencana terjalin harmonis dan tak mengenal pengelompokan etnis (Muthia, 2017). 
Peneliti berasumsi bahwa masingmasing masyarakat etnis Tionghoa dan Sunda di Jalan Surya Kencana Bogor melakukan akomodasi komunikasi, yaitu suatu tindakan penyesuaian, pemodifikasian dan pengaturan perilaku individu sebagai sebuah respon terhadap pihak lain. Tindakan akomodatif ini biasa dilakukan oleh seseorang saat melakukan komunikasi dengan orang lain agar memperpendek jarak sosial diantara mereka. Tindakan ini kadang kala dilakukan secara sadar ataupun tidak disadari oleh pelakunya. Salah satu poin penting dalam Teori Akomodasi Komunikasi (Communication Accomodation Theory) atau yang sering disingkat dengan CAT adalah bahwa dalam berkomunikasi setiap orang memiliki pilihan masing-masing dalam menentukan sikap komunikasinya yaitu dengan cara konvergensi, divergensi, dan akomodasi berlebihan (West dan Turnet, 2008).

Telah banyak penelitian terdahulu yang mengkaji mengenai akomodasi komunikasi etnis Tionghoa dan non Tionghoa. Seperti pada penelitian yang dilakukan oleh Cindy (2013). Penelitian tersebut dilatarbelakangi oleh individu dalam perusahaan yang berasal dari budaya yang berbeda. Pimpinan perusahaan merupakan etnis Tionghoa. Mayoritas pegawai perusahaan berasal dari etnis Tionghoa. Terdapat pula sejumlah pegawai yang berasal dari etnis lain, yaitu etnis Jawa. Tujuan penelitian tersebut adalah untuk mengetahui proses akomodasi komunikasi antarbudaya etnis Cina dan Jawa di Karangturi Group Purwokerto. Hasil penelitian tersebut menunjukkan bahwa terjadi proses konvergensi dan divergensi. Konvergensi yang terjadi yaitu pada saat para pimpinan perusahaan yang merupakan etnis Tionghoa mengonstruksi komunikasi yang dapat dipahami oleh pegawainya yang berasal dari etnis Jawa. Sedangkan divergensi yang terjadi yaitu penggunaan bahasa Mandarin yang dituturkan oleh sesama etnis Tionghoa di perusahaan tersebut, baik antara pimpinan dengan pegawai ataupun sesama pegawai. Hal ini berakibat pada rasa kurang nyaman yang dialami oleh etnis Jawa karena dianggap sebagai etnis yang berbeda di lingkungan perusahaan tersebut.

Penelitian selanjutnya yang mengkaji proses akomodasi antara masyarakat etnis Tionghoa dan non Tionghoa juga dilakukan oleh Atok (2016) yang mengidentifikasi proses akomodasi komunikasi yang dilakukan oleh mahasiswa etnis Tionghoa dan Non-Tionghoa di Fakultas Farmasi Universitas Pancasila. Jika dibandingkan dengan fakultas-fakultas lain yang ada di Universitas Pancasila, Fakultas Farmasi memiliki jumlah etnis Tionghoa yang lebih banyak jika dibandingkan dengan etnis lainnya. Kondisi ini cukup unik dikarenakan Universitas Pancasila merupakan kampus yang didominasi oleh etnis Jawa dan Sunda. Hasil penelitian tersebut menunjukkan bahwa mahasiswa etnis Tionghoa dan Non-Tionghoa di Universitas Pancasila masing-masing melakukan konvergensi dan divergensi. Konvergensi komunikasi yang dilakukan yaitu dengan cara menggunakan bahasa Indonesia dalam berkomunikasi. Proses divergensi yang ditemukan pada beberapa mahasiswa etnis Tionghoa adalah saat bertemu dengan sesama etnisnya selalu berkomunikasi dengan bahasa Hokkian.

Aurelia (2018) juga melakukan penelitian mengenai akomodasi komunikasi antara etnis Tionghoa dan non Tionghoa. Ia mendeskripsikan proses akomodasi komunikasi yang dilakukan oleh masyarakat etnis Tionghoa dan non Tionghoa di Petak Sembilan, Glodok, Jakarta. Penelitian tersebut dilatarbelakangi kelamnya sejarah hubungan masa lalu antara etnis Tionghoa dan non Tionghoa di daerah Petak Sembilan, Glodok. Penelitian tersebut menemukan bahwa baik etnis Tionghoa dan Non-Tionghoa di Petak Sembilan, Glodok melakukan konvergensi, divergensi dan akomodasi berlebihan. Konvergensi yang ditemukan pada penelitian tersebut adalah menyapa lawan bicara yang merupakan etnis lain sesuai dengan sapaan etnisnya. Misalnya mas dan mba untuk menyapa etnis Jawa, dan ko ko dan ci ci untuk menyapa etnis Tionghoa. Divergensi yang ditemukan pada penelitian tersebut adalah penggunaan dialek daerah oleh 
etnis Tionghoa dengan intonasi suara yang tinggi dan kecepatan berbicara yang sulit diimbangi oleh etnis lain. Sedangkan akomodasi berlebihan yang didapat adalah penggunaan dialek khas etnis Tionghoa yang dilakukan oleh etnis non-Tionghoa.

Peneliti beranggapan bahwa masih relevan untuk dilakukan penelitian selanjutnya mengenai akomodasi komunikasi pada masyarakat etnis Tionghoa dan non-Tionghoa. Terlebih jika kita melihat kondisi yang terjadi di Surya Kencana yang mana masyarakatnya dapat hidup berdampingan secara damai dengan kondisi etnis Tionghoa merupakan etnis mayoritas di sana. Little John dan Foss (2016) menjelaskan bahwa kekuasaan sosial menjadi bagian integral dalam teori Akomodasi Komunikasi. Individu dengan status sosial yang lebih rendah akan cenderung menyesuaikan diri dengan individu yang memiliki status sosial yang lebih tinggi. Hal ini dikarenakan orang yang memiliki status sosial yang lebih tinggi memiliki modal sosial yang lebih banyak. Lalu bagaimana proses akomodasi yang dilakukan oleh masyarakat etnis Tionghoa dan etnis Sunda di Surya Kencana, Bogor?

Pada penelitian ini, akan mengkaji akomodasi komunikasi yang terjadi antara masyarakat etnis Tionghoa dengan masyarakat etnis Sunda Jalan Surya Kencana di RW 2 dan RW 6. Berdasarkan pengamatan yang dilakukan, etnis Tionghoa di Jalan Surya Kencana memiliki status sosial yang lebih tinggi jika dibandingkan dengan etnis Sunda di sana. Etnis Tionghoa Surya Kencana umumnya pemiliki toko atau restoran dan membuka toko atau restorannya di jalan utama, yaitu Jalan Surya Kencana. Sedangkan etnis Sunda di sana biasanya merupakan pedagang biasa, bahkan ada yang bekerja mengurus rumah etnis Tionghoa di sana. Apakah dengan kondisi seperti ini masyarakat etnis Sunda saja yang akan melakukan penyesuaian diri dikarenakan status sosial mereka yang lebih rendah?

Berdasarkan latar belakang yang dikemukakan di atas, maka tujuan penelitian ini adalah untuk mengetahui proses akomodasi komunikasi yang dilakukan oleh etnis Tionghoa dan etnis Sunda di Surya Kencana, Bogor.

\section{METODOLOGI PENELITIAN}

Pada Teori Akomodasi Komunikasi, dinyatakan bahwa dalam proses komunikasi, peserta komunikasi seringkali terlihat melakukan peniruan satu sama lain. Proses ini tidak dapat dideskripsikan dengan angka-angka atau data statistik, tetapi harus ditemukan secara mendalam pada proses interaksi secara langsung. Oleh sebab itulah, digunakan metode kualitatif dalam penelitian ini untuk melihat bagaimana penyesuaian komunikasi yang dilakukan oleh etnis Tionghoa dan Sunda di Surya Kencana, Bogor.

Riset kualitatif merupakan suatu penelitian yang menggali dan memaknai makna pada seseorang atau kelompok orang dalam sebuah permasalahan sosial. Umumnya, riset kualitatif dipakai untuk mengkaji mengenai kehidupan masyarakat, histori, fenomena sosial, permasalahan sosial, dan sebagainya (Creswell, 2016). Riset kualitatif juga digunakan untuk mendalami fenomena yang dialami subjek penelitian, seperti tingkah laku, sudut pandang, motivasi, tindakan secara menyeluruh dengan menggambarkannya ke dalam narasi atau katakata (Moleong, 2006).

Pada penelitian ini, yang menjadi subjek penelitian adalah etnis Tionghoa dan etnis Sunda yang berada di Jl. Surya Kencana, Bogor, Jawa Barat. Kedua etnis tersebut dipilih karena berkesesuaian dengan tujuan utama dari penelitian ini, yaitu agar mampu mendeskripsikan pengalaman akomodasi atau adaptasi yang mereka lakukan. Pengalaman ini dideskripsikan berdasarkan sudut pandang yang mereka alami.

Teknik pengumpulan data yang dilakukan pada penelitian ini adalah wawancara mendalam dan observasi pada saat wawancara. Wawancara dilakukan terhadap dua narasumber yang merupakan perwakilan dari masingmasing etnis. Narasumber pada penelitian ini adalah Mardi Liem yang merupakan etnis Tionghoa dan merupakan pemilik restoran di Jalan Surya Kencana. Narasumber selanjutnya 
adalah Na'ah yang merupakan etnis Sunda yang bekerja di salah satu rumah warga etnis Tionghoa di Jl. Surya Kencana. Kedua etnis dipilih disebabkan intensitas interaksi dan komunikasi yang dilakukan kedua informan lebih sering dilakukan dengan etnis yang berbeda. Mardi Liem lebih sering berinteraksi dengan etnis Sunda, sedangkan Na'ah lebih sering berinteraksi dengan etnis Tionghoa.

\section{HASIL DAN PEMBAHASAN}

\section{Etnis Tionghoa mengalami "Amnesia" terhadap Bahasa Leluhur}

Hadirnya etnis Tionghoa di Kota Bogor bukanlah tanpa sebab. Hal ini dikisahkan oleh Mardi Liem yang menjelaskan bahwa terbentuknya Jalan Surya Kencana ini merupakan hasil bentukan Belanda sekitar tahun 1750. Mardi Lim sendiri merupakan menantu di rumah yang ia tempati. Rumah yang sekaligus restoran itu merupakan milik ayah dan ibu mertuanya. Ia mengisahkan bahwa ayah mertuanya merupakan keturunan generasi ketiga yang telah tinggal di Jalan Surya Kencana. Ini artinya kakek buyut dari istri Mardi Lim merupakan generasi pertama yang datang langsung dari Tiongkok ke Indonesia.

Mardi Liem sendiri pun sama, ia juga merupakan keturunan generasi keempat di keluarganya. Sebagai sesama generasi keempat di keluarga masing-masing, baik Mardi Liem dan istri sudah tidak dapat berbahasa leluhur mereka, yaitu bahasa Kanton dan Hokkien.

Menurut pengalaman Mardi Liem sebagai etnis Tionghoa, penyebab ia, istrinya dan orang-orang seusianya yang juga merupakan sesama etnis Tionghoa sudah tidak dapat lagi berbahasa leluhur mereka. Ia pribadi hanya dapat berbahasa leluhurnya dalam konteks jual beli atau keuangan dan bahasa saapaan sehari-hari kepada sahabat. Hal ini, dikisahkan Mardi Liem, disebabkan represif yang dilakukan rezim Orde Baru terhadap etnis Tionghoa di Indonesia. Bahkan menurut Mardi Liem, Jawa Barat merupakan daerah di Indonesia yang mengalami refresif holistik, atau represif menyeluruh terhadap ketionghoaan mereka. Refresif atau kekangan ini membuat Mardi Liem dan sesama etnisnya menjadi takut. Mereka pun akhirnya mengganti namanya yang semula Liem Ciam Yong menjadi Mardi dan harus rela tidak dapat mengenyam pendidikan ketionghoaan.

Akibat dari refresif yang dilakukan rezim Orde Baru terhadap etnis Tionghoa, menyebabkan Mardi Liem dan keluarganya memiliki kehati-hatian dalam melakukan sesuatu atau bahkan berkomunikasi. Ia akan sangat hati-hati dalam menggunakan bahasa ketika akan melakukan percakapan di mana pun dan kepada siapa pun. Walaupun ia sedang berada di lingkungan yang mayoritas etnis Tionghoanya, Mardi Liem tidak akan menggunakan bahasa Hokkien atau bahasa Mandarin untuk berkomunikasi dengan sesama etnisnya. Hal ini lebih disebabkan adanya kekhawatiran terhadap orang-orang sekitar yang tidak suka dengan etnis Tionghoa di zaman Orde Baru. Orang tua Mardi Liem mengajarkan kepadanya dan saudara-saudaranya untuk berkomunikasi dengan menggunakan Bahasa Indonesia saja. Dikhawatirkan jika mereka berkomunikasi dengan bahasa Hokkien atau Mandarin terdapat etnis Non-Tionghoa yang merasa tersinggung.

Sulit bagi Mardi Liem untuk dapat berkomunikasi dengan bahasa leluhurnya, bahasa Hokkien, terlebih menggunakan bahasa Mandarin yang merupakan bahasa nasional di Tiongkok. Hanya sedikit sekali bahasa leluhurnya yang dapat ia pahami dan ucapkan. Untuk bahasa dalam konteks jual beli atau keuangan yang masih digunakan dan dipahami oleh Mardi Liem dan etnis Tionghoa di sekitarnya adalah ce pek, go pek, go ceng, se ceng, ce tiao, dan sebagainya. Istilah-istilah tersebut sering ia gunakan ketika melayani pelanggan di restorannya. Bahkan istilah tersebut banyak digunakan di pasar di areal sekitar pemukimannya. Sedangakan bahasa sehari-hari yang masih ia gunakan seperti ciak yang artinya makan, wa yang artinya saya, dan $l u$ yang artinya kamu. Begitu dahsyatnya refresif kekangan yang dilakukan pada rezim Orde Baru terhadap Mardi Liem dan etnis Tionghoa 
lainnya hingga ia menyebut apa yang mereka alami ini dengan istilah "amnesia". Ia dan etnis Tionghoa di Indonesia, khususnya di Jawa Barat dibuat lupa dengan budaya dan bahasa yang mereka miliki dari generasi sebelumnya.

\section{Semakin 'Kasar', Semakin Akrab}

Upaya "mengamnesiakan" etnis

Tionghoa yang dilakukan rezim Orde Baru ini mau tak mau membuat mereka harus memiliki strategi untuk dapat bertahan. Mereka pun melakukan berbagai macam strategi agar dapat diterima di masyarakat lingkungan mereka. Mardi Liem, keluarga istrinya dan etnis Tionghoa di Jalan Surya Kencana sangat berbaur dengan masyarakat sekitar. Kepada warga etnis Sunda di lingkungannya, Mardi Liem akan menggunakan bahasa Sunda dan bahasa Indonesia. Begitupun dengan warga etnis Sunda di sana, akan menggunakan bahasa Indonesia yang dicampur dengan bahasa Sunda dalam berkomunikasi dengan etnis Tionghoa. Biasanya warga etnis Sunda-lah yang terlebih dahulu menyapa Mardi Liem dengan bahasa Sunda, seperti: "Kumaha kang damang?" Ia pun dengan senang hati menjawabnya dengan bahasa Sunda juga, "Ohh pangestu". Namun ketika sudah panjang lebar terlibat percakapan, dan pada proses percakapan tersebut terdapat bahasa Sunda yang kosa katanya tidak dapat Mardi Liem tuturkan, maka ia akan menggantinya dengan menggunakan bahasa Indonesia.

$\begin{array}{rrrr}\text { Mardi } & \text { Liem } & \text { merasa } & \text { nyaman } \\ \text { menggunakan } & \text { bahasa } & \text { Sunda } & \text { ketika }\end{array}$ berkomunikasi dengan etnis Sunda. Menurutnya dalam penggunaan bahasa Sunda tersebut terdapat unsur keakraban. Terlebih ia dan tetangganya yang beretnis Sunda seringkali mengobrol dengan menggunakan bahasa Sunda 'kasar'. Contohnya pada saat bertegur sapa dengan tetangga yang sudah lama tidak berjumpa seperti berikut: "Sia teh kamana wae?". Kalimat tersebut dapat berkonotasi negatif bagi sebagian orang yang paham akan tingkatan dalam bahasa Sunda. Apalagi menurut Mardi Liem, kalimat tersebut diucapkan dengan intonasi dan tekanan suara yang cukup lantang.
Namun menurut Mardi Liem penggunaan bahasa Sunda 'kasar' tersebut merupakan bentuk keakrabannya dengan tetangganya yang beretnis Sunda. Tidak ada unsur kemarahan atau pun hujatan dalam kalimat tersebut. Penggunaan intonasi dan tekanan suara yang lantang merupakan bentuk eskpresi dari antusiasnya ketika bertemu dengan tetangga yang sudah lama tidak ia jumpai. Menurutnya, semakin 'kasar' bahasa Sunda yang mereka gunakan, menunjukkan tingkatan keakraban yang semakin tinggi.

$\mathrm{Na}$ 'ah menyatakan pernyataan yang kurang lebih sama dengan Mardi Liem. Ia juga selalu menggunakan bahasa Indonesia yang dicampur dengan bahasa Sunda pada saat berkomunikasi dengan Etnis Tionghoa. Na'ah mengakui tidak ada perbedaan cara berkomunikasi antara ia dengan sesama etnis Sunda ataupun antara ia dengan etnis Tionghoa, semua sama saja. Menurutnya masyarakat etnis Tionghoa di Jalan Surya Kencana sudah fasih dan lancar dalam menggunakan bahasa Sunda. Oleh sebab itulah ia dan etnis Sunda lainnya tidak segan untuk berkomunikasi dengan menggunakan bahasa Sunda dengan etnis Tionghoa Jalan Surya Kencana.

\section{Bangga Disapa "Ko Ko"}

Pada saat berkomunikasi dengan etnis Tionghoa, etnis Sunda di Surya Kencana akan menyapa mereka dengan sapaan berdasarkan etnisnya. Seperi cerita $\mathrm{Na}$ 'ah, ia memanggil tetangganya yang etnis Tionghoa dengan sapaan ko ko untuk menyapa laki-laki, dan $c i$ ci untuk menyapa perempuan. Namun menurut Na'ah, sapaan ko ko dan $\mathrm{ci}$ ci tersebut hanya untuk tetangganya yang memiliki jarak usia yang tidak terlalu jauh dengannya. Untuk tetangganya yang memiliki usia yang jauh lebih tua, Na'ah akan menyapanya dengan sapaan lain seperti kung kung atau po po. Kepada tetangga etnis Tionghoa yang mereka hormati, maka Na'ah dan etnis Sunda lainnya akan menyapa dengan sebutan bapak atau ibu.

Cerita Na'ah tersebut diamini oleh Mardi Liem. Ia menyatakan bahwa perilaku yang cukup unik ditampilkan oleh etnis Sunda 
di Surya Kencana. Mereka sangat pandai membahasakan seseorang yang lebih tua atau yang mereka hormati. Panggilan 'bapak' sering ia dapatkan dari tetangganya dari etnis Sunda yang memiliki usia lebih muda dibawahnya.

Mardi Liem sangat mengapresiasi tetangganya yang beretnis Sunda ketika dirinya dipanggil ko ko. Pada saat itu ia merasa keberadaanya sebagai etnis Tionghoa sangat diterima di lingkungannya. Ia merasa menjadi etnis Tionghoa seutuhnya.

Perasaan nyaman yang ia rasakan saat ini sangat bertolak belakang dengan kondisi masa lalu pada rezim Orde Baru. Pada saat itu ia dan keluarganya memiliki prasangka negatif terhadap etnis Sunda dan etnis lainnya di lingkungan sekitarnya. Kala itu, ia akan merasa sangat tidak nyaman jika terdapat seseorang dari etnis lain yang memanggilnya dengan sapaan $k o$ ko. Dirinya merasa seakan-akan menjadi masyarakat yang dipinggirkan dan ditekan. Ia merasa panggilan ko ko tersebut sebagai sebuah ejekan atas perbedaan etnis yang ia dan lawan bicaranya miliki. Apalagi jika ia disapa dengan penambahan huruf 'ng' dalam kata ko ko, sehingga menjadi 'ngkoh', rasa tidak nyamannya semakin menjadi. Padahal menurut Mardi Liem, penggunaan kata ko ko dan ci ci pada zaman dahulu sebelum rezim Orde Baru merupakan sebuah bentuk penghormatan kepada seseorang yang disapa tersebut. Pada masa sekarang, rasa bangga yang ia rasankan pada saat disapa dengan sebutan ko ko oleh para tetangganya yang beretnis Sunda. Hal ini menujukkan identitas etnisnya sebagai etnis Tionghoa.

Pernah suatu ketika Mardi Liem disapa dengan panggilan ko ko oleh seseorang anak berusia delapan tahun. Tindakan anak tersebut sempat membuat Mardi Liem merasa tidak nyaman. Hal ini dikarenakan tindakan anak tersebut merupakan suatu pebuatan yang tidak sopan. Menurutnya tidak patut jika seorang anak-anak memanggilnya dengan sapaan ko ko. Hal ini dikarenakan kata ko ko memiliki arti kakak laki-laki dalam bahasa Indonesia. Sedangkan anak tersebut memiliki usia yang kurang lebih sama dengan anaknya Mardi Liem.
Lebih pantas jika anak tersebut memanggilnya dengan kata ncek dalam dialek Hokkian atau shu shu dalam bahasa Mandarin yang artinya paman. Namun Mardi Liem memaklumi tindakan anak tersebut. Ia menduga anak-anak tersebut tidak memahami arti dari kata ko ko yang sebenarnya.

\section{Etnis Tionghoa mengucapkan kata Alhamdulillah?!}

Mardi Liem akan selalu membuka diri untuk berkomunikasi dengan menggunakan bahasa Sunda dengan etnis Sunda di lingkungannya. Ia pun tak segan untuk menggunakan istilah-istilah yang lebih spesifik lagi seperti kata Alhamdulillah yang memiliki nuansa keagamaan. Mardi Lim menceritakan pernah suatu saat ia menggunakan kata Alhamdulillah ketika berkomunikasi dengan etnis Sunda di lingkungan tempat tinggalnya. Reaksi heran diberikan oleh etnis Sunda tersebut kepada Mardi Liem, "Loh, kok si koko bias ngomong Alhamdulillah?". Mardi Liem memaklumi keheranan yang direaksikan oleh tetangganya tersebut. Menurutnya, kata Alhamdulillah tidak masalah jika diucapkan oleh siapa pun karena makna kata tersebut menurutnya menyimbolkan suatu hal yang bersifat universal.

Upaya yang dilakukan oleh Mardi Liem tersebut tidak lebih sebagai bentuk pendekatan dirinya kepada lawan bicaranya. Ia mempunyai prinsip hidup 'di mana langit dipijak, di situ langit dijunjung'. Ketika ia berkomunikasi dengan etnis Sunda yang beragama Islam, maka ia akan berupaya berkomunikasi serupa dengan orang Islam.

Na'ah menceritakan bahwa hubungan antara etnis Sunda dan Tionghoa di Surya Kencana sangatlah cair. Isu SARA dan keagamaan hampir tidak terjadi di lingkungannya. Satu sama lain saling menghormati. Bahkan etnis Tionghoa memberikan perhatian khusus kepada etnis Sunda pada saat Hari Raya Lebaran tiba. Etnis Tionghoa rutin membagi-bagikan bingkisan lebaran kepada etnis Sunda yang merayakan lebaran. Pada saat Hari Raya Imlek pun, etnis Sunda akan terlibat dalam pesta rakyat yang 
diselenggarakan oleh etnis Tionghoa Surya Kencana.

$\mathrm{Na}$ 'ah menyatakan, sekedar ucapan 'selamat lebaran' dari etnis Tionghoa bukanlah hal yang aneh bagi etnis Sunda. Sebagaimana ia dan sesama etnis Sunda lainnya selalu mengucapkan selamat lebaran juga untuk tetangganya yang beretnis Tionghoa. Akan tetapi Na'ah menyatakan, ucapan Alhamdulillah yang diucapkan etnis Tionghoa saat berinteraksi dengan mereka dirasa tidak perlu dilakukan. $\mathrm{Na}$ 'ah memahami perdedaan agaman yang ia dan lawan bicaranya miliki, jadi ucapan Alhamdulillah yang diucapkan etnis Tionghoa dirasa sedikit berlebihan.

\section{Pembahasan}

Masyarakat etnis Tionghoa dan Sunda di Surya Kencana memiliki perbedaan budaya. Perbedaan budaya tentunya terkait juga dengan perbedaan bahasa sebagai sarana berkomunikasi. Sulitnya untuk memisahkan antara komunikasi dan budaya karena keduanya memiliki interelasi dan kedekatan yang sangat erat. Budaya dapat mempengaruhi bagaimana cara seseorang dalam berkomunikasi, begitupun sebaliknya. Miripnya persepsi satu budaya dengan budaya lain saat berinteraksi dapat dimungkinkan memberikan kesamaan makna pula terhadap sebuah sebuah realitas sosial (Samovar, et al. 2010). Lalu bagaimana komunikasi yang terjadi dengan orang-orang yang memiliki perbedaan budaya dan persepsi?

Masyarakat etnis Tionghoa dan etnis Sunda di Surya Kencana yang tadinya memiliki perbedaan budaya, pada akhirnya melakukan akomodasi, yaitu suatu tindakan penyesuaian, pemodifikasian dan pengaturan perilaku individu sebagai sebuah respon terhadap pihak lain. Orang akan melakukan akomodasi komunikasi dengan orang lain agar memperpendek jarak sosial diantara mereka yang dilakukan dengan sadar ataupun tidak (West dan Turner, 2008).

Etnis Tionghoa Surya Kencana awalnya melakukan akomodasi yang kemudian menjadi asimilasi dengan keterpaksaan, terutama pada rezim Orde Baru. Sebagaimana dijelaskan oleh
Suryadinata (2014) bahwa program asimilasi yang digalakkan pada rezim Ode Baru kepada etnis Tionghoa memang terkesan memaksa. Program ini tak lain bertujuan agar etnis Tionghoa Indonesia meningggalkan identitas ' 'ke-Tionghoa-an' mereka. Selain itu program ini memiliki tujuan agar etnis Tionghoa Indonesia memiliki jiwa 'ke-Indonesia-an' yang lebih.

Banyak upaya yang dilakukan agar etnis Tionghoa Indonesia menjadi lebih 'Indonesia'. Diantaranya adalah dengan mengganti nama mereka menjadi nama orang Indonesia pada umumnya, seperti yang dialami oleh etnis Tionghoa di Surya Kencana, Bogor. Hal serupa juga ditemukan pada etnis Tionghoa di Surabaya (Kurniawan, 2012) dan di Semarang (Suharyo, 2013) yang harus rela mengganti nama mereka menjadi nama Indonesia atau nama Indonesia yang dipadukan dengan nama Barat.

Upaya lainnya yang terpaksa dilakukan oleh Etnis Tionghoa adalah berkomunikasi dengan menggunakan bahasa Indonesia. Mereka dilarang untuk menggunakan bahasa Mandarin atau bahasa dialek Tiongkok lainnya serta menutup sekolah yang mengajarkan bahasa Mandarin dan mewajibkan generasi etnis Tionghoa pada rezim Orde Baru untuk mempelajari bahasa Indonesia (Adam, 2019).

Akhirnya etnis Tionghoa di Surya Kencana melakukan konvergensi, atau upaya adaptasi terhadap perilaku komunikatif lawan bicaranya (West dan Turner, 2008) agar dapat berbaur dengan komunitas sosial di lingkungan tempat tinggalnya, yaitu menyesuaikan komunikasi verbal dan non-verbal ketika berkomunikasi. Dijelaskan oleh Adler dan Rodman sebagaimana dikutip dari Djuarsa (2002) bahwa komuniasi verbal merupakan komunikasi yang menggunakan bahasa lisan (oral communication) serta bahasa tulisan (written communication), seperti sturktur pesan, gaya bahasa, dan daya tarik pesan. Sedangkan komunikasi non-verbal menurut Samovar, et al. (2010) adalah bentuk komunikasi yang merupakan hasil rangsangan dalam suatu latar 
komunikasi seperti konesik, proksemik dan paralinguistik.

Upaya komunikasi konvergensi yang dilakukan etnis Tionghoa Surya Kencana secara verbal adalah dengan menggunakan bahasa Sunda dan bahasa Indonesia ketika berinterkasi dengan etnis Sunda. Etnis Sunda Surya Kencana pun melakukan upaya konvergensi ketika berinteraski dengan etnis Tionghoa, yaitu dengan cara menyapa etnis Tionghoa dengan sapaan sesuai etnisnya seperti ko ko, ci ci, dan sebagainya. Upaya konvergensi yang dilakukan oleh masing-masing etnis ini dilakukan agar mempermudah proses komunikasi dan agar dapat lebih mengakrabkan diri satu sama lain. Temuan yang sama juga terdapat pada penelitian yang dilakukan Alviana dan Salam (2015). Penelitian tersebut menemukan bahwa Suku Jawa dan Suku Melalyu di Riau melakukan konvergensi dalam aspek bahasa dan sapaan sesuai etnisnya. Begitupun yang ditemukan pada penelitian Aurelia (2018). Etnis Tionghoa dan non-Tionghoa di Petak Sembilan, Jakarta melakukan konvergensi komunikasi dengan cara saling menyapa sesuai asal etnis alwan bicaranya.

Konvergensi dilakukan kerena adanya ketertarikan diantara peserta komunikasi. Giles dan Smith menjelaskan terdapat beberapa faktor yang menyebabkan seseorang tertarik dengan orang lainnya: pertama: adanya kemungkinan untuk melakukan interaksi selanjutnya dengan lawan bicara, kedua: adanya kemampuan seseorang dalam berkomunikasi, dan ketiga: adanya perbedaan status dari peserta komunikasi (Giles dan Clair, 1979). Baik etnis Tionghoa dan etnis Sunda Surya Kencana memiliki ketertarikan dalam melakukan konvergensi komunikasi dikarenakan faktor pertama, yaitu adanya kemungkinan untuk melakukan interaksi selanjutnya dengan lawan bicara. Interaksi antara kedua etnis terjadi setiap hari dan akan tersu terjadi selama mereka bertempat tinggal di lingkungan tersebut.

Hasil penelitian ini membantah penyataan Little John dan Foss (2016) yang menjelaskan bahwa individu yang memiliki status sosial lebih rendah akan cenderung menyesuaikan diri dengan individu yang memiliki status sosial yang lebih tinggi disebabkan modal sosial individu dengan status sosial lebih tinggi yang lebih banyak. Walaupun etnis Tionghoa memiliki status sosial yang lebih tinggi malahan mereka melakukan penyesuaian diri dengan etnis Sunda yang memiliki status sosial yang lebih rendah. Walau awalnya konvergensi komunikasi yang dilakukan oleh etnis Tionghoa Surya Kencana secara terpaksa, akan tetapi lama-kelamaan rasa nyaman yang membuat mereka terus melakukan konvergensi komunikasi. Terlebih etnis Sunda Surya Kencana memberikan umpan balik yang positif dengan cara melakukan konvergensi komunikasi pula dengan etnis Tionghoa. Hal ini sebagaimana dijelaskan oleh Suheri (2019), jika individu sudah melakukan konvergensi dengan baik, maka konvergensi yang dilakukan tersebut dapat memperbaiki komunikasi serta mendapatkan umpan balik yang positif.

Pada proses akomodasi komunikasi, terdapat sebuah upaya untuk menonjolkan kekhasan yang dimiliki oleh peserta komunikasi baik verbal maupun non-verbal, yang disebut dengan divergensi. Pada penelitian ini, divergensi yang dilakukan etnis Tionghoa Surya Kencana adalah merasa senang jika disapa dengan sapaan etnisnya ( $k o k o$, ci ci, dll) oleh etnis Sunda Surya Kencana. Rasa senang ini disebabkan karena bangga lingkungan sekitarnya menganggap dirinya sebagai etnis Tionghoa. Sedangkan divergensi yang dilakukan oleh etnis Sunda Surya Kencana adalah menggunakan bahasa Sunda dengan porsi yang melebihi batas. Tindakan ini kadangkala membuat etnis Tionghoa menjadi kewalahan dalam memberikan umpan balik ketika berkomunikasi. Temuan yang berbeda justru ditemukan pada penelitian terdahulu.

Pada penelitian yang dilakukan oleh Cindy (2013) divergensi yang dilakukan oleh individu etnis Tionghoa di Karangturi Group Purwokerto adalah menggunakan bahasa Mandarin ketika berinteraksi dengan sesama etnisnya di kantor. Tindakan ini menimbulkan rasa tidak nyaman yang dirasakan etnis nonTionghoa di perusahaan tersebut. Upaya 
divergensi yang dilakukan oleh individu pada perusahaan Karangturi Group Purwokerto disebabkan adanya alasan kekuasaan. Hal ini dilakukan oleh pimpinan perusahaan untuk menunjukkan superioritasnya.

Berbeda halnya pada kasus masyarakat Surya Kencana, divergensi komunikasi dilakukan oleh masing-masing etnis untuk mempertahankan identitas etnis masing-masing. Etnis Tionghoa merasa bangga jika disapa dengan sapaan yang sesuai identitasnya karena keberadaan mereka sebagai etnis Tionghoa dianggap ada di lingkungannya. Sedangkan etnis Sunda selalu memulai dan menggunakan bahasa Sunda ketika berkomunikasi dengan etnis Tionghoa Surya Kencana agar etnis Tionghoa merasa bahwa jika tinggal di daerah Sunda harus dapat berkomunikasi dengan bahasa Sunda.

Upaya lain yang dilakukan dalam proses akomodasi komunikasi adalah akomodasi berlebihan, yaitu pada saat peserta komunikasi melakukan akomodasi namun secara berlebihan dalam mengatur, memodofikasi serta memberikan respon kepada lawan bicaranya. Terkadang komunikator memiliki niat baik, namun sering disalah artikan oleh pihak lawan bicara (West dan Turner, 2008). Akomodasi berlebihan ditemukan dalam proses akomodasi antara etnis Tionghoa dan etnis Sunda di Surya Kencana. Etnis Sunda Surya Kencana berupaya melakukan pendekatan dengan etnis Tionghoa Surya Kencana dengan cara menyapa sesuai panggilan etnisnya. Upaya ini dilakukan dengan niat baik karena ingin mendekatkan diri dengan lawan bicara. Namun ternyata terdapat ketidaknyamanan yang dirasakan etnis Tionghoa dewasa pada saat etnis Sunda yang masih anak-anak menyapa mereka dengan sebutan ' $k o$ ko'. Anak-anak tersebut secara tidak sadar sudah berperilaku kurang sopan terhadap etnis Tionghoa dewasa. Sayangnya rasa ketidaknyamanan yang dirasakan etnis Tionghoa ini tidak langsung disampaikan kepada etnis Sunda. Akibatnya hal tersebut masih sering terjadi. Dilain kesempatan, etnis Tionghoa juga berupaya untuk mendekatkan diri kepada etnis Sunda sebagai lawan bicaranya, yaitu dengan mengucapkan 'Alhamdulillah'. Namun upaya ini dirasakan oleh etnis Sunda sebagai suatu tindakan yang berlebihan.

Akomodasi berlebihan juga ditemukan pada proses akomodasi antar etnis. Seperti pada penelitian pada etnis Jawa dan Entis Minang. Etnis Minang melakukan akomodasi berlebihan dengan cara mereplika gaya bicara etnis Jawa. Hal ini dilakukan etnis Minang karena merupakan salah satu upaya mereka untuk mendekatkan diri sebagai etnis minoritas di lingkungan tempat tinggalnya. Namun upaya ini dianggap oleh etnis Jawa sebagai suatu yang berlebihan (Sari, 2019).

Morrisan (2009) menyatakan bahwa seseorang akan memberikan penghargaan terhadap upaya konvergensi yang dilakukan orang lain dengan tepat, baik dan sesuai situasi serta kondisi. Namun seseorang akan tersinggung apabila upaya konvergensi yang dilakukan orang lain tersebut dilakukan dengan tidak pantas. Pada beberapa kasus proses akomodasi komunikasi lintas budaya, para peserta komunikasi yang melakukan akomodasi berbelihan sering kali tidak mengetahui jika perbuatan atau tingkah laku mereka telah membuat lawan bicaranya menjadi tidak nyaman. Ada baiknya ketidaknyamanan yang dirasakan oleh salah satu peserta dalam proses akomodasi tersebut dinyatakan secara terus terang kepada lawan bicaranya. Cara penyampaiannya pun dilakukan senyaman mungkin agar lawan bicara tidak tersinggung dan sakit hati. Hal ini dilakukan agar proses akomodasi komunikasi berjalan lancar dan efektif.

Riset yang dilakukan Ibrahim dan Bambang (2015) menemukan bahwa masyarakat non-Tionghoa secara umum masih memiliki rasa etnosentrisme yang tinggi. Hal ini berdampak pada perasaan yang menganggap diri "selalu benar" dan "orang baik" jika dibandingkan dengan etnis Tionghoa. Akibatnya perlakuan-perlakuan yang kurang baik selalu diterima oleh etnis Tionghoa. Diantaranya mendapatkan perlakukan tidak adil dalam kehidupan khsusnya sosial politik. 
Juditha (2015) juga menemukan hubungan yang kurang harmonis antara etnis Tionghoa dengan etnis Bugis di Makassar. Konflik antara kedua etnis tersebut kerap hadir. Hal ini diakibatkan oleh kuatnya stereotip dan prasangka antara kedua etnis tersebut. Pengalaman masa lalu masih menjadi penghalang hubungan kedua etnis tersebut untuk berinteraksi. Akibarnya Etnis Tionghoa yang minoritas semakin tersisihkan, sedangkan etnis Bugis yang mendominasi semakin superior.

Berbeda halnya yang terjadi di Surya Kencana, Bogor. Masyarakat etnis Tionghoa dan etnis Sunda di Surya Kencana mencerminkan kehidupan lintas budaya yang harmoni seutuhnya. Kedua etnis saling mengakomodasi agar selalu hidup rukun dan damai. Masa lalu yang kelam diantara kedua etnis tidak menjadi penghalang bagi kedua etnis untuk selalu melakukan akomodasi. Menjadi seorang Tionghoa yang Nyunda (bebahasa Sunda) merupakan salah satu identitas budaya mereka. Hal ini sebagaimana tergambar dalam penelitian yang dilakukan Susanti dan Koswara (2017) yang menemukan perilaku kesundaan yang diterapkan oleh masyarakat etnis Tionghoa di kota Bandung. Kesundaan memiliki arti bentuk nyata dari nilai-nilai filosofis dalam budaya Sunda sehari-hari yang diimplementasikan dalam karya seni, bentuk perilaku dan nilai-nilai yang dianut. Kesundaan ini dimiliki dan diakui oleh etnis Tionghoa melalui proses pembelajaran secara terusmenerus melalui proses interaksi dan komunikasi.
Kesundaan ini pula yang terdapat pada etnis Tionghoa Surya Kencana. Melalui proses akomodasi komunikasi yang dilakukan, mereka mempelajari bagaimana harus berkomunikasi dengan etnis Sunda, begitupun sebaliknya. Akomodasi merupakan upaya yang dilakukan individu untuk memantau dan menyesuaikan perilaku lawan bicaranya selama proses interaksi (Rohim, 2009). Pada proses pemantauan dan penyesuaian tersebut terdapat proses pembelajaran yang dilakukan etnis Tionghoa terhadap budaya Sunda. Begitu pun sebaliknya, etnis Sunda melakukan pembelajaran terhadap budaya Tionghoa selama proses akomodasi. Pembelajaran tersebut dilakukan terus-menerus selama kedua etnis saling berinteraksi.

Proses pembelajaran terhadap suatu budaya tertentu harus dilakukan oleh tiap-tiap individu, terlebih jika berada di suatu lingkungan budaya yang dominan seperti yang terjadi pada etnis Tionghoa di Suryakencana ini. Hal yang sama juga dilakukan oleh mahasiswa ekspatriat dalam program Bahasa Indonesia untuk Penutur Asing (BIPA) di Lembaga Bahasa Internasional Fakultas Ilmu Pengetahuan Budaya Universitas Indonesia (Anindita dan Woelandari 2020). Mereka yang merupakan mahasiswa dari berbagai negara di dunia melakukan pembelajaran budaya dan bahasa Indonesia selama tinggal di Indonesia. Dapat disimpulkan bahwa perlu adanya upaya akomodasi bagi suatu individu ketika berada dalam lingkungan budaya yang berbeda dengannya.

Tabel 1. Proses Akomodasi Komunikasi Etnis Tionghoa dan Etnis Sunda di Surya Kencana, Bogor

\begin{tabular}{|c|c|c|}
\hline Etnis & Akomodasi & Tindakan Komunikasi \\
\hline \multirow[t]{3}{*}{ Tionghoa } & Konvergensi & $\begin{array}{c}\text { Menggunakan bahasa Indonesia } \\
\text { dan bahasa Sunda ketika } \\
\text { berkomunikasi dengan etnis } \\
\text { Sunda }\end{array}$ \\
\hline & Divergensi & $\begin{array}{l}\text { Senang disapa dengan sapaan } \\
\text { etnisnya (cth. ko ko) oleh etnis } \\
\text { Sunda karena merasa diri } \\
\text { sebagai Etnis Tionghoa }\end{array}$ \\
\hline & Akomodasi berlebihan & $\begin{array}{l}\text { Mengucapkan kata } \\
\text { "Alhamdulillah" ketika }\end{array}$ \\
\hline
\end{tabular}


JURNAL PUSTAKA KOMUNIKASI, Volume 4, No. 1, Maret 2021, hlm 91-104

\begin{tabular}{|c|c|c|}
\hline & & $\begin{array}{l}\text { berkomunikasi dengan etnis } \\
\text { Sunda yang beragama Islam }\end{array}$ \\
\hline \multirow[t]{3}{*}{ Sunda } & Konvergensi & $\begin{array}{c}\text { Menyapa etnis Tionghoa } \\
\text { dengan sapaan sesuai etnisnya } \\
\text { (ko ko, } c i c i, \text { dsb. })\end{array}$ \\
\hline & Divergensi & $\begin{array}{l}\text { Menggunakan bahasa Sunda } \\
\text { dengan porsi berlebihan }\end{array}$ \\
\hline & Akomodasi berlebihan & $\begin{array}{c}\text { Anak-anak menyapa etnis } \\
\text { Tionghoa dewasa dengan } \\
\text { sebutan 'ko ko' }\end{array}$ \\
\hline
\end{tabular}

Sumber: Hasil Penelitian, 2021

\section{SIMPULAN}

Proses akomodasi komunikasi yang terjadi dalam konteks komunikasi lintas budaya banyak ditemui di Indonesia. Salah satu proses akomodasi yang banyak ditemui adalah antara Etnis Tionghoa dan etnis non-Tionghoa. Proses akomodasi yang dilakukan oleh etnis Tionghoa selama ini ternyata dilakukan dengan sadar dan penuh keterpaksaan. Hal ini dikarenakan trauma politik masa lalu yang dialami etnis Tionghoa. Namun seiring waktu, proses tersebut dilakukan natural dan apa adanya. Tujuan dilakukannya proses akomodasi antara etnis Tionghoa dan Sunda adalah agar tercapaianya komunikasi lintas

\section{DAFTAR PUSTAKA}

Adam, A. W. (2019). Tionghoa dan KeIndonesia-an: Komunitas Tionghoa di Semarang dan Medan. Yayasan Pustaka Obor Indonesia: Jakarta.

Alviana, S. dan Salam, N.E. (2015). Strategi akomodasi komunikasi dalam interaksi antar budaya Suku Melayu (tempatan) dan Suku Jawa di Desa Bukit Gajah Kecamatan Ukui Kabupaten Pelalawan Provinsi Riau. Jurnal Online Mahasiswa Fakultas Ilmu Sosial dan Ilmu Politik Universitas Riau. Diakses dari:

https://media.neliti.com/media/publicat ions/32565-ID-strategi-akomodasikomunikasi-dalam-interaksi-antarbudaya-suku-melayu-tempatan.pdf.

Anindita dan Woelandari, N. (2020). Praktik komunikasi antarbudaya pada budaya yang efektif. Efektivitas komunikasi lintas budaya akan menciptakan keharmonisan.

Penelitian ini tentu saja jauh dari sempurna, terutama pada durasi waktu penelitian yang dilakukan. Akibat pandemi Covid-19, peneliti tidak dapat melakukan penelitian secara maksimal terutama dalam hal observasi. Untuk itu diharapkan dilakukan penelitian selanjutnya dengan melakukan teknik observasi mendalam untuk mengamati interaksi langsung yang terjadi antara etnis Tionghoa dan etnis Sunda (atau etnis nonTionghoa lainnya) dengan detil dalam melakukan akomodasi komunikasi.

mahasiswa ekspatriat dalam program Bahasa Indonesia untuk penutur asing (BIPA). Jurnal Pustaka Komunikasi, 3(1), 24-36. https://doi.org/10.32509/pustakom.v3i1 .966

Aryana, I.G.M. 2017. Kuasa di balik harmoni: Etnografi Kritis Relasi Etnis Tionghoa dan Etnis Bali di Desa Pupuan, Tabanan, Bali. Jurnal Kajian Bali, 07(01), 1-16. https://doi.org/10.24843/JKB.2017.v07 .i01.p01

Atabik, A. (2016). Percampuran Budaya Jawa dan Cina: Harmoni Dan Toleransi Beragama Masyarakat Lasem. Jurnal Sabda, Vol. 11: 1-11. https://doi.org/10.14710/sabda.11.1.111 
Atok, M. (2016). Komunikasi Akomodasi Mahasiswa Etnis Tionghoa dan Non Tionghoa Fakultas Farmasi, Universitas Pancasila. Skripsi. Fakultas Ilmu Komunikasi Universitas pancasila. Jakarta.

Aurelia, G. (2018). Komunikasi Akomodasi Masyarakat Etnis Tionghoa dan Non Tionghoa di Petak Sembilan, Glodok, Jakarta. Skripsi. Fakultas Ilmu Komunikasi Universitas pancasila. Jakarta.

Cindy, F. (2013). Proses Komunikasi Akomodasi Antarbudaya Etnis Cina dan Etnis Jawa di Perusahaan Karangturi Group Purwokerto. Diakses dari: $\quad$ http://ejournal.uajy.ac.id/4251/1/jurnal\%20il miah.pdf.

Carey, P. (2015). Orang Cina, Bandar Tol, Candu, dan Perang Jawa. Komunitas Bambu: Depok.

Creswell, J. W. (2016). Research Design Pendekatan Kualitatif, Kuantitatif, dan Mixed. Pustaka Pelajar: Yogyakarta.

Djuarsa, S.S. (2002). Teori Komunikasi. Universitas Terbuka: Jakarta.

Giles, H. and St. Clair, R. N. (1979). Language and Social Psychology. Blackwell: Oxford.

Ibrahim, S.M., dan Bambang, A. (2015). Hambatan Komunikasi Antar Budaya Pada Aspek Ras (Analisis Kritis Pada Kasus Indonesia - Tionghoa). Bricolage: Jurnal Magiser Ilmu Komunikasi, 1(1). http://dx.doi.org/10.30813/bricolage.v1 i02.1629

Juditha, C. (2015). Stereotip dan Prasangka dalam Konflik Etnis Tionghoa dan Bugis Makassar. Jurnal Ilmu Komunikasi, 12 (1), 87-104. https://doi.org/10.24002/jik.v12i1.445

Kurnaiwan, B. (2012). Penggunaan Nama Barat oleh Etnis Tionghoa di Surabaya. Jurnal Lakon, 1(1), 12-20. http://dx.doi.org/10.20473/lakon.v1i1.1 911

Littlejohn, S.W., dan Karen A.F. (2016). Ensiklopedia Teori Komunikasi. Kencana: Jakarta.

Moleong, L. J. (2006). Metodologi Penelitian Kualitatif. Remaja Rosdakarya: Bandung.

Morrisan \& Wardhany Andy Corry. (2009). Teori Komunikasi. Ghalia Indonesia: Jakata.

Muthia, K. (2017). Komunikasi Antar Budaya Etnis Keturunan Tionghoa Dengan Non Tionghoa di Jalan Suryakencana Kota Bogor (Studi Pada Identitas Etnis dan Pola Komunikasi). Skripsi. Universitas Pancasila.

Onghokham. (2008). Anti Cina, Kapitalisme Cina, dan Gerakan Cina: Sejarah Etnis Cina di Indonesia. Komunitas Bambu. Depok.

Putro, Y.A., Atmaja, H. T., \& Sodiq, I. (2017). Konflik Rasial Antara Etnis Tionghoa Dengan Pribumi Jawa di Surakarta Tahun 1972-1998. Journal of Indonesian History, 6(1), 66-74. Diakses dari: https://journal.unnes.ac.id/sju/index.ph p/jih/article/view/20031/9458

Rohim, S. (2009). Teori Komunikasi Perspektif, Ragam dan Aplikasi. Penerbit Rineka Cipta: Jakarta.

Rustopo. (2007). Menjadi Jawa: Orang-orang Tionghoa dan Kebudayaan Jawa di Surakarta 1895-1998. Ombak: Yogyakarta.

Samovar, L., Porter, R., \& McDaniel, E. (2010). Komunikasi Lintas Budaya. Salemba Humanika: Jakarta.

Sari, N.O.P. \& Rahardjo, T. (2019). Akomodasi Komunikasi Antarbudaya (Etnis Jawa Dengan Etnis Minang). Interaksi Online, 7(4). Diakses dari https://ejournal3.undip.ac.id/index. php/interaksi-online/article/view/24928 Suhandinata, J. (2018). WNI Keturunan Tionghoa dalam Stabilitas Ekonomi 
dan Politik Indonesia. PT. Gramedia Pustaka Utama: Jakarta.

Suharyo, (2013). Pola Namamasyarakat keturunan Tionghoa. HUMANIKA, 18(2), $1-12$. https://doi.org/10.14710/humanika.18.2

Suheri. (2019). Akomodasi Komunikasi. Jurnal Network Media, 2(1), 40-48. https://doi.org/10.46576/jnm.v2i1.447

Suryadinata, L. (2010). Etnis Tionghoa dan Nasionalisme Indonesia. Penerbit Buku Kompas: Jakarta.
Susanti, S., dan Koswara, I. (2017). Menyatukan Perbedaan Melalui Seni Budaya Sunda. Jurnal MediaTor, 10(2), 143-155. https://doi.org/10.29313/mediator.v10i 2.2739

West, R. dan Lynn H.T. (2008). Pengantar Teori Komunikasi: Analisis dan Aplikasi (Buku 2) (Edisi 3). Salemba Humanika: Jakarta.

Vermeulen, J.T. (2010). Tionghoa di Batavia dan Huru-Hara 1740. Komunitas Bambu: Depok 